\title{
Employee Contributions to Brand Equity
}

\author{
Betsy DuBois Gelb \\ Deva Rangarajan
}

Viewing employees as elements of a brand or as "brand ambassadors" means that almost any policy can affect brand equity. Resource allocation for brand-building requires understanding what differentiates "our brand" in order to focus resources on the employees who provide that difference. Employees' commitment to the brand increases when they know how they can contribute. Management actions matter-from small issues like free coffee to large issues like mass layoffs. (Keywords: Brand Equity, Employee Commitment, Brand Ambassadors, Brand Differentiation)

T he influence of employees on profits has been widely documented. In industries ranging from hotels to insurance to retailing, customer-focused employees can increase their company's "share of wallet." ${ }^{1}$ However, employees likewise affect brand equity, with Starbucks's baristas as a shining example ${ }^{2}$ and rogue traders in the financial services industry a tarnished one. How can firms improve organizational policies and resource allocation so that employees increase not just profits, but also brand equity? We conducted a qualitative study to develop information that could guide such improvement.

\section{Brand Equity: Perceptions}

A brand is a form of intellectual property, "the central nexus of communication between an enterprise and its consumers." ${ }^{3}$ The term "brand equity" commonly refers to what distinguishes a brand from its commodity counterpart in the favorable perceptions and feelings of customers and potential customers, thus reducing the price elasticity of goods or services that carry its name. ${ }^{4}$ Grannell attributes those favorable perceptions and feelings to a combination of recognition, associations, and judgments made by a buyer. ${ }^{5}$

Other authors point out that because brand equity resides in the perceptions of brand, it differs from brand value, the price at which a company could sell its brand 
Betsy DuBois Gelb is the Larry J Sachnowitz Professor of Marketing \& Entrepreneurship in the Bauer College of Business at the University of Houston.

Deva Rangarajan is an associate professor of marketing at the Vlerick Business School and an associated professor at the University of Gent, both in Belgium. to another company. ${ }^{6}$ However, it may be viewed as a component of brand value, along with other benefits a customer receives, such as the convenience provided by a channel partner. ${ }^{7}$

Brand equity also differs from profitability. While profit can show up quickly, possibly by cutting costs, increasing brand equity involves investing for longer-term contingencies, both to build and to sustain profit. High brand equity can provide, for example, the ability to retain customers despite price-cutting by competitors, the ability to charge more than competitors, and the ability to withstand bad news such as a product or service failure. It can also lead to successfully placing one's brand name on a new product, the kind of thinking that led Procter \& Gamble to launch a franchise network of Tide Dry Cleaners. Furthermore, as goods and even services become more commonly imitated, having a trusted brand name may become a product's only distinguishing feature.

\section{Studying a Universal Issue}

In setting out to advise managers on this topic, we realized that the impressions left by baristas and rogue traders are simply extreme examples; the link between employee actions and brand equity appears universal. Obviously, service organizations find employee contributions to be critical, but marketers of tangible products increasingly count on services to enhance the customer experience. Consumer marketers have obvious brand equity concerns, yet employee influence may be greater in the business-to-business arena, in which networks of relationships built on mutual trust are critical. Therefore, if an employee leaves the company, customers lose the other half of that trust relationship, whether it is a sales rep who handles that customer's account, a manager who adapts the product to that customer's specific needs, or a logistics specialist who fine-tunes delivery to the customer's specifications. Once that happens, brand equity can be reduced significantly.

Furthermore, viewing employees as contributors to brand equity goes beyond for-profit organizations. As pointed out by Andreasen and Kotler, ${ }^{8}$ nonprofit organizations want a range of constituencies to know who they are and what they stand for: commonly they need to attract volunteers, donors, and sponsors, as well as "customers" who use their services. Fortunately, employees of nonprofits may find it particularly socially acceptable to communicate the who-they-are/ what-they-stand-for message, even more than would be the case in for-profit organizations, providing a disproportionately high payoff for employees' role in branding.

Thus, any organization benefits from hiring and training employees to build trust and credibility for their brand, then evaluating them on the extent to which they do so.

The point is that these are dollar-consequential issues. Managers must justify investing extra dollars in hiring and training brand-building employees, reinforcing brand understanding and commitment among employees through internal 
communications, and rewarding actions that build brand equity. They must likewise justify dollars to retain brand-enhancing employees-for example, those who personify friendliness, competence, or concern for customers. Firms that market multiple brands must justify not only dollars spent to build the equity of each brand, but those spent to build the equity of the parent company as a brand. Davies et al. note that most service organizations depend upon the associations stakeholders make with their corporate names. ${ }^{9}$

Such associations become a branding issue for management in many circumstances, but certainly do so when a company considers large-scale layoffs. Shedding the cost of 1,000 employees may reduce loss or increase profit in the short term, but if service levels decline and/or former employees denigrate a company they believe has treated them unfairly, brand equity may over time fall significantly. The Economic Times, for example, reports that companies in India, including General Electric and Citigroup, have begun helping downsized employees find work to avoid damaging the way their "brand" would be perceived otherwise. ${ }^{10}$

What do managers say about the influence on brand equity by a given employee, a category of employees, or the entire employee population? How can managers protect and enhance that brand equity?

\section{A Two-Sided Issue}

While the focus is often on the positive contributions of employees to a brand, the negative effects may be even more important. Consider the Houston Chronicle headline: "Pilots say labor talks hurting United." The news story began: "Sluggish labor negotiations have put another stain on United Airlines public image since it merged with Continental Airlines, the head of the Continental Airlines pilots' union said Tuesday after hundreds of pilots picketed the company shareholders meeting in New York."11

Usually, it doesn't take hundreds of visibly hostile employees. A single disgruntled employee may produce a YouTube video seen by millions. An employee offering a bribe to someone in a foreign government may lead to federal court in the United States, with attendant publicity. A textbook on e-marketing recounts what the authors refer to as "Dell's Hell," a two-year period of literally millions of online customer complaints after one blogger posted:

"I just got a new Dell laptop and paid a fortune for the four-year, in-home service.... The machine is a lemon and the service is a lie ... DELL SUCKS. DELL LIES. Put that in your Google and smoke it, Dell."12

For Dell, the trigger for the critical complaint was the outsourcing of service to India in 2005. It may appear that as a marketer of goods, Dell is less vulnerable to employee actions tarnishing the brand than would be the case for a marketer of services, and similarly less likely to benefit from employee actions that boost it. However, Lusch and Vargo point out that all firms offer service, if service is defined as using one's knowledge, skills, and capabilities for the benefit of another. ${ }^{13}$ Thus these issues can affect any manager-even one at a company that does not emphasize its own brands. Such a company may be a supplier to or a distributor of one or many 
branded products; if so, its employees may well influence the perceptions of those brands.

Employees can "make or break" brands in two related ways. They can be elements of the brand; or they can be ambassadors for the brand, specifically for actions beyond job-related roles.

\section{Employees as Brand Elements}

Employees are most likely to be perceived as elements of the brand when they interact with customers, but that interaction can be viewed broadly. Hogan and her co-authors focus on "touchpoints," noting that the brand is the sum of the customer's experiences with the product or company. For a car dealer, they suggest, it may begin with the website, and will include all facets of a visit to the dealership. Then: "Fast forward to ... delivery of the car: it's a boost ... if the gas tank is full and your favorite radio station is playing as you get in. Subtract a few points if the salesperson asks you to give him all 'excellent' ratings on the customer satisfaction survey you'll be receiving in two weeks."14

Harquail notes that ideally the expectations of customers concerning a brand will be met by helping employees to internalize the brand's desired attributes, so that they naturally express those attributes in their behaviors. ${ }^{15}$ However, meeting expectations is not the whole story, according to the Kano model, which categorizes buyer criteria for evaluating products. According to this model, evaluation of a purchase is based on: must-be requirements that affect satisfaction only if absent; onedimensional requirements that increase satisfaction in linear fashion as they increase; and unexpected "attractive" aspects that cause delight. ${ }^{16}$

Buyer delight in response to the unexpected surely enhances brand equitybut almost by definition, Kano's "attractive" aspect of a purchase cannot be standardized or it would not be unexpected. Thus employees - the least standardized aspect of a brand-are the most likely sources of the best experiences. Bitner, for example, tells the story of a family that always traveled with their teddy bears; when they returned to their hotel room they saw that "the maid had arranged our bears very comfortably in a chair. The bears were holding hands." ${ }^{17}$

What might have motivated that maid-or any other employee? King and Grace credit the behavior by managers that employees see as derived from "human qualities." ${ }^{18}$ Their research builds on a model of an employee branding process by Miles and Mangold, one that shows the corporation as a source of messages that lead to a psychological contract with the employee. That psychological contract, Miles and Mangold say, motivates employees to project the desired organizational image through "their demeanor, appearance, and manner of interacting with customers." ${ }^{19}$ These authors see lower turnover, greater employee satisfaction, higher service quality, customer retention, and word-of-mouth communication as outcomes when an organization treats its employees well to model their treating customers well. Supporting this perspective, Pugh found that positive feelings on the part of employees predicted that they would display positive emotion during their interactions with customers, ${ }^{20}$ and a study of hotel industry employees linked employee commitment, satisfaction, and identification with the brand specifically to brand equity. ${ }^{21}$ 


\section{Employees as Brand Ambassadors}

A second facet of the relationship of employees to brand equity is their contributions as brand ambassadors. Beyond the role of their job description, they can represent the brand to customers, potential customers, the public at large, and even to potential new employees. According to Martin et al., brand ambassadors can be "created" if firms educate employees about their importance in maintaining the corporate reputation. $^{22}$

Employees as brand ambassadors can also listen. They may have friends or neighbors who comment on the brand, or its competitors. A focus on organizational culture that fosters brand equity led Schultz and Hatch to observe that brands need to evolve, and that employees who bring feedback from the outside can help them do so. ${ }^{23}$ In addition, employees can defend the brand. One case study evoked the comment that "when there's negative press coverage of [the product] you'll need to be able to tell friends and family what it's really like." 24

\section{Our Method: High Level Interviews}

Despite the wealth of research demonstrating that employees can contribute to brand equity, many organizations face cost-cutting mandates that threaten management efforts to enhance those contributions. Therefore, we set out to examine how organizations assess employee contributions and what they do to enhance them. We expected the views of managers on these topics to offer guidance for better focusing of resources, with examples of situations where cost-cutting may be shortsighted.

Our method was a qualitative study, interviewing managers representing a range of companies in the United States and in Europe, some of them business to business and some consumer marketers. We asked how employees in their organizations affect brand equity, probing their influence at three levels: the employee population as a whole; groups of customer-facing employees in particular; and one or more key employees, often those in leadership positions.

We took into account the fact that customer-facing employees may work for dealers, retailers, or other value-added resellers who represent a brand but do not work for the company that owns it. As Hughes and Ahearne have pointed out, one reason to build brand equity is to "energize" those who represent the brand down the channel so that they represent it vigorously and well. ${ }^{25}$

Our information sources were 15 organizations that spanned not only geography, but organizational type-some primarily service providers, some marketing tangible products. Only three offered brands with a cachet that might bring them to mind as unusually focused on brand equity, and eight of the 15 market to other businesses, not to consumers. On our list were:

- a multi-product Asian industrial goods manufacturer that markets through industrial distributors;

- a Belgian chocolatier with a worldwide presence;

- a Scandinavian global industrial goods manufacturer that mainly sells directly to its customers; 
- a multinational service organization active in the automotive glass replacement market;

- a U.S.-based IT outsourcing giant;

- a global manufacturer of products that include both household appliances and industrial goods;

- a global manufacturer of high-tech equipment and monitors based in Western Europe;

- a small marketing research firm based out of Western Europe;

- three U.S. retail chains, one marketing food and related goods, one marketing clothing, and one a general merchandise department store chain;

- a U.S.-headquartered financial services company;

- a U.S. manufacturer of a widely purchased food product ingredient;

- a U.S.-based worldwide marketer of consumer packaged goods; and

- a Belgian-based bank catering to both B2C and B2B customers.

We conducted individual interviews with marketing executives responsible for brand-related decisions and also with human resources executives; on average they reported 17 years of experience in their current position or a similar one. We asked what they do currently or have done previously to assess the contribution of employees to the brand, and whether the focus has been all employees, one or more subgroups, or individuals. We requested examples. Then we asked what they are doing currently or have done in the past to increase that contribution, again with examples. Finally, we asked what a company could do to assess and/or to increase the contribution of employees to the brand.

\section{Results}

The observations of those we interviewed varied widely; some focused on individuals in leadership roles, some on groups of employees, and some on the entire workforce. We analyzed the answers by noting common themes, rather than "counting" how many respondents expressed a particular perspective.

The first theme deals with the substance of the brand-what differentiates it from a commodity service or unbranded tangible product, or from branded competitors. Here a frequent message was that whichever group of employees provides those differentiating characteristics are the ones basically contributing to brand equity, doing so as elements of the brand. A suggestion to hire individuals who exemplify the differentiating characteristics arose in this context.

The other theme concerns employees as brand ambassadors. The executives we interviewed observed that any individual in a workforce can potentially affect brand equity not only by how they perform their jobs, but also by who they are, how they feel about the company, and what they say about it.

\section{Employees as Brand Differentiators}

The first perspective, that employees as elements of a brand can differentiate that brand from generics or from its competitors, recognizes that a specific set of those 
employees provide that differentiation. An executive of a Houston-based statewide supermarket chain suggested considering what makes a given brand distinctive and, from there, which categories of employees produce that distinction. He elaborated as follows:

"Let me offer an example from my own industry of two extremes: Walmart and Whole Foods. For Walmart, what enables them to back up the low price image that distinguishes their brand is sourcing and procurement expertise. So the employees who have those jobs make their brand what it is. By contrast, the Whole Foods brand involves expertise on the part of employees standing in the vitamin aisle or behind the meat counter suggesting recipes. So it's a different set of employees that make the brand what it is for Whole Foods."

The same executive, when asked how the employees' contribution to the brand could be assessed, suggested starting with numbers that many supermarkets already at least estimate: the value of a customer walking in for convenience vs. the value of a loyal customer drawn in consistently by the store's distinctive brand. What drives repeat business from that loyal customer, he noted, is brand distinctiveness and the employees who produce it. So it may be possible to calculate the incremental number of customers who are attracted by the brand-and therefore attributable to the employees who make a given brand "what it is" — then multiply that number by the extent to which those customers are more profitable than someone who walks in just because it's convenient, but may not ever come back.

Interestingly, that same supermarket chain executive unintentionally provided an example months after the interview of what an employee as "brand ambassador" contributes to brand building in contrast to contributing to profit. As Exhibit 1 shows, he e-mailed individuals on his contact list, sending them the link to a major Houston Chronicle story about the opening of a new store by his chain. Most individuals who received the e-mail don't live near the store and wouldn't shop there, so they would not contribute to profit. All, however, would perceive that the chain was growing and that this particular expansion move was viewed by the employee reporting it and by the newspaper as worthy of note-quite possibly affecting the image of the brand.

\section{EXHIBIT I. Building Brand Value but Probably Not Short-Term Profitability}

Fiesta Food Markets opened a new store on the Southwest side of Houston in June of 2012. An extensive story with four-color pictures reported the event in the Houston Chronicle on June 28, 2012. By 10 a.m. that day, the senior author of this article had an e-mail from the Fiesta executive interviewed for this article: "Hope you saw our story in the Chronicle; here's the link. Presumably, he sent the same e-mail to others on his contact list; he is a sincerely enthusiastic booster of his employer's supermarket chain.

continued on next page 
Can anyone say that his enthusiasm put dollars in the revenue column of that store? The case is a difficult one to make. In Houston in the summer, anyone familiar with the melting time of ice cream shops only close to home, and in the fourth largest city in the U.S., a given store location will be "close to home" for very few people on any given e-mail contact list.

However, did he build the brand? Certainly. Implicitly, he offered at least three messages: "We are expanding. We are viewed as important by the city's only newspaper. And I am excited about our progress."

To justify an investment in employees beyond their contribution to profits - to illustrate what "ambassadors" do to build a brand-here is an easy-to-understand example.

Continuing in a retail context, but looking at employee contributions differently, a human resources executive who has worked at Sears and at The Gap said the contributions of employees to enhancing brand equity come from their ability to turn non-buyers into buyers. In that context, she envisioned a non-buyer as disappointed by the retailer's brand for wasting his or her shopping trip, in contrast to a buyer happily displaying a purchase to others, increasing brand equity among all concerned.

She viewed employee contributions to increasing the number of buyers in three ways. First, one set of employees determine what goods are stocked, in what numbers, in what models (Sears) or sizes/colors (The Gap). If they do a poor job, the proportion of store traffic that consists of non-purchasers rises. Second, perceived service level is determined by the local employees the customer sees, and if the service level is less than excellent there is no reason to expect the customer to want to buy. Third, those local employees "match" customer and merchandise: "If what you have in inventory in her size is a purple sweater, the employee has the job of making purple the ideal choice."

Given a hypothetical \$100 "typical" sale, this HR executive estimated that employees provide $25 \%$ of the value of the brand. "Everything that brought the customer into that store-location, advertising, reputation, and pricing-represents $60 \%$ of the customer's purchase price, so if we sold everything at full price I'd say $40 \%$, but we don't-so $25 \%$," she estimated.

Asked how companies like those she had worked for enhance employees' contributions to brand equity, she pointed out a specific effort by Sears in California. Because appliance salespersons often encountered Spanish-speaking customers, the company set out to hire Spanish-speaking individuals who felt comfortable using that language on the sales floor in a few stores, as an experiment. Sears experienced double-digit appliance sales increases in those stores, she reports, a result that suggested to her that brand equity was enhanced by that proportion among Spanishspeaking buyers.

A human resources consultant previously associated with Sears pointed out the effort that company had made in the 1990s to quantify the contribution of employees. $^{26}$ She said that they built their brand during that decade by hiring the right people and training them about the links between their actions and profitability, 
but evaluation and retention were also tremendously consequential. If employees knew that going beyond merely satisfying customers would show up in evaluation, they made those efforts, she said. Furthermore, they would stay with the firm if they saw the workplace as a friendly culture that engaged them as well as paying competitively or better. In her view, "procurement" is the heart of a great brand, and in a service industry "the procurement issue is people."

In other words, she saw the basic ingredients affecting brand equity for a retailer (since Sears was her example) as the human resources. She offered two very different examples. The first involves those who devise and implement inventory systems: she observed that they need to be fanatical in avoiding stockouts to prevent the customer from wasting a trip and de facto being sent to visit the store of a competitor. Her other example involves top management. She noted that they must plan for the possibility that competitors who seem to be inferior (discount stores, in Sears' case) will attract "their" customers-and that they must have a counter-offensive ready.

\section{Additional Examples of Differentiating the Brand}

Among others we interviewed, some made the same point using different terms. At Belron, which operates in the automotive glass replacement market in 27 countries, the CEO saw the attitudes of their frontline service employees towards the customer as what differentiates Belron from other local players. This UK-headquartered company invests heavily in training their employees not only in the Belron way of fixing glass problems, but also in other aspects of customer service including courteousness, friendliness, and assurance. These approaches have resulted in increased levels of customer satisfaction and customer referrals, thereby contributing to positive word-of-mouth for the brand, the CEO reported. He saw the investment in employees as boosting Belron's reputation and thereby the price that customers are willing to pay for Belron services.

Suppose a company's brand stands for "expertise," as is the case for Insites Consulting, a Belgian startup market research firm. Since their inception in the late 1990s, Insites positioned itself as "the market expert" on the emerging trend of using the World Wide Web as a market research platform. In a sense, the totality of their brand equity rested with the employees who executed market research projects for client firms. Two decades after their founding, they are located in several countries and have just made a foray into to the U.S. market, success their top management attributed to their "expertise" positioning-and delivery.

In B2B industries, the role of expertise increasingly is seen by top management as a key differentiating point in the struggle to avoid being regarded as commodities. One author of this study helps train B2B firm employees to focus their expertise on areas that matter most to customers, partly so that as new services involving technical products/solutions are introduced, customers will have enough confidence in their brand to be willing to try the unfamiliar.

Financial services firms likewise base their brand equity on expertise, and an HR executive at one such firm headquartered in Chicago said that she perceives two potential contributions to brand equity by a salesperson of financial services products. First, she described as the salesperson's role in customer success in investing, 
because in her industry a brand is assessed by the financial success of its customers. Second, she saw her firm's salespersons as building the brand through leadership in conveying the values of the company to co-workers, to build the "good name" that attracts better employees, leads to better teamwork, and aligns all employees with organizational values such as honesty and a customer focus.

Like the supermarket chain executive quoted earlier in this discussion, she suggested investigating "where the customer finds value in the brand." One example she offered was a company shifting to an international market, where competition would differ from their previous experience. Once market research offers indications of how the company seems better than its new competition to at least some buyers, then management knows where its advantages lie and can associate them with specific employees. Those employees, in other words, lift the company beyond the generic.

A high-end Belgian chocolatier exemplifies this perspective. Neuhaus, the company in question, increasingly focuses on delivering an excellent in-shop customer experience to their customers, so that the brand encompasses innovative, high-quality chocolate products plus the in-shop experience. Neuhaus invests heavily in training their shop managers and customer-facing employees on the concept of "elegance" and making sure that customers experience a feeling of luxury and being cared for when they enter a Neuhaus store.

On a far broader scale, similar reasoning has motivated significant investment by a global manufacturer of products that include both household appliances and industrial goods. Based out of Western Europe, this company boasts around 120,000 employees. Historically, they had exerted limited efforts to understand the employee-brand equity relationship, but beginning in 2010, top management increasingly felt that employee contributions to the firm needed a more astute assessment.

They started by testing one-region or one-country interventions, such as employee training or incentives, to increase what they defined as employee engagement. Then they used a measurement tool, the Net Promoter Score, to assess the impact of the brand on customers; this tool asks a customer to score from 0 to 10 how likely he or she would be to recommend the brand/company to a friend or colleague. ${ }^{27}$ Initial results from a region-specific survey indicated that regions where employees were more engaged also demonstrated higher Net Promoter scores. However, the company is cautious about making sweeping claims until it tests the results further.

Similarly, a large Swedish manufacturer of industrial goods, realizing the importance of human capital on brand equity, has begun investing in significant training of its field sales and service force on soft skills aimed at managing customer relationships. Another global, industrial goods manufacturer has taken the same concept further. Based on their history of working with third-party resellers, they are creating dealer development initiatives aimed at protecting their brand equity, although those who represent it are not their own employees but the employees of their dealers.

Employees play at least two other roles highlighted by those we interviewed. One is to "localize" an international brand. That role is exemplified by managers at 
Cognizant, an information technology firm previously highlighted in this journal, ${ }^{28}$ to allay concerns among European clients about offshoring to India, as described in Exhibit 2.

Another role for employees arises when a company changes ownership, changes its name, or both. The HR director of a U.S. company that changed its name observed that top management hoped it could be perceived as an entirely new brand-with 10,000 employees. She said that the point of the name change was to become innovative and to be perceived that way. So employees were explicitly asked to become innovative to exemplify the change, even if in small but symbolic ways. If previously they had always entertained a customer at a particular restaurant, for example, they might select a different one and explain with a smile: "We're a new company now."

\section{EXHIBIT 2. Branding at Cognizant}

A provider of IT services to businesses, the company was started in 1994 as the technology arm of Dun \& Bradstreet, with operations mainly based out of India. Now a global organization, Cognizant is listed as a Fortune 1000 company and on the Forbes "25 Fastest Growing Technology Companies in America" list for a sixth straight year.

Having achieved that high level of success in the U.S., Cognizant turned its attention to increasing its position and business in Europe. How do employees differentiate this brand from other IT consulting firms for European clients? The company perceived that clients would have qualms about offshoring, and their response was to link the Cognizant brand name to a local General Manager for each operating company in Europe. That decision means that customers can interact with one specific individual, in their own country, to request service or to pose questions once a consulting project begins. A global brand "becomes" a local brand; in other words, thanks to the ability of those individuals to handle whatever question or challenge comes their way, and they become valued elements of that brand.

\section{Brand Equity as a Recruiting Tool}

We asked an HR executive for an international consumer packaged goods company how she viewed the link between employee actions and brand equity. Her immediate response: "We consider our people part of our brand."

She also emphasized that an outstanding brand attracts the best employees, and those employees in turn increase that brand equity. Her company attracts the "most talented" workforce, she believes, because of their image as one of the world's most iconic brands. The message that "our brand is special" is one that employees spread not only to customers and potential customers, but also convey as brand ambassadors to potential employees. Such messages attract more and better job 
applicants, providing an opportunity to hire better employees, and thus, full-circle, more brand-enhancing "ambassadors."

Then the company works hard at retention. After a recent acquisition, merging the compensation systems left some employees with what would have been pay cuts. However, as many as possible of those employees were "grandfathered" to avoid those cuts. Her interpretation was that a top brand must have top-talent people, and the costs of attracting and keeping them are sensible investments in that brand.

Her examples of such investments included purchasing an expensive recruiting technology system, so that each applicant receives a response to his or her application and those applications flow to the right recruiters. Additional costs have included a survey of all employees and a sophisticated system of communicating with employees so that they are "engaged" with the brand in concrete waysmotivated, for example, to express via social media comments that spread the brand's message.

To the extent that employees do spread the brand's message, regardless of their job description, they function as brand ambassadors. However, that description need not be limited to current employees. For example, a bank in Belgium asked its retired employees to act as brand ambassadors in their local communities, offering information about the bank's financial products.

\section{What These Results Mean for Managerial Actions}

\section{Almost Any Policy Can Affect Brand Equity}

Policies that can influence brand equity cover a broad spectrum of managerial concerns: operations, raw materials, cell phone use, complaint handling, legal action, and even taxes. While managers may not immediately relate these fields to branding, those we interviewed placed emphasis on the danger to brands from a wide range of policies. Such policies can undermine the efforts of the most skilled and devoted employees if they are made without consideration of the consequences for brand equity.

Oursler provides a range of decisions that led to calls for boycotts of a brand. ${ }^{29}$ She includes: an airline that refused to refund a ticket sold to a Vietnam veteran who had to cancel his flight after being diagnosed with terminal cancer; and an athletic shoe manufacturer that was targeted by kangaroo lovers for its use (since discontinued) of kangaroo skin for soccer cleats.

Another example of a brand-damaging policy comes from a well-known company with a policy permitting hands-free use of cell phones by employees while they drive. A marketing employee, complying with that policy, prompted a \$22 million judgment against the company after a woman was seriously injured when the employee sideswiped her car. The case generated national publicity because of qualms about the use of cell phones while driving. ${ }^{30}$

The obvious lesson for managers is that once employees are recognized as part of the brand, any policy must be examined for its potential brand-related consequences. In August 2012, the New York Times devoted the entire top half of a page 
in its Sunday business section to discuss the poor handling by public relations professionals of a complaint to Samsung that a change in its toner cartridges had made them incompatible with its own printers. ${ }^{31}$ Only a day earlier, the same newspaper had reported massive, negative internet attention for a decision by Progressive Insurance Company's attorneys to fight in court an award to the estate of their own policy holder, fatally injured in a crash, on a legal technicality. ${ }^{32}$ Again in the New York Times, a 2013 front-page banner headlined Apple's (legal) avoidance of "billions" in taxes by locating subsidiaries in nations that required no record keeping or tax returns. ${ }^{33}$ Here we have an example of brand equity potentially damaged by a company's tax planners.

Quite possibly none of these issues was seen as a brand-related concerninitially. However, suppliers of a wide range of professional services-and of manufactured products from factories that harm animals or endanger workers-can find in these examples a reason to re-examine any managerial decision that could harm the brand.

\section{Employee-Focused Issues Affect Brand Equity}

Three other broad implications for brand equity flow from these results.

- The employees who matter most are those who make the brand what it is, whether by cutting costs through supply chain management skills, by delighting customers through face-to-face interactions, by influencing customer wants to match what the brand can in fact deliver, and by creating a brand reputation and a work environment attractive to the potential hires who will improve brand equity even more. Managers need to identify those employees.

- Whether employees are viewed as "elements" of the brand or also as brand ambassadors, they need to know what the brand stands for and how they can contribute to brand equity. They also need the motivation to deliver that contribution.

- Managers need to provide that motivation. Company policies are one way, and treating employees well so that they treat customers well is vital.

These results should strongly affect the hiring, training, managing, and evaluating of employees. The tasks for top management are to estimate the long-term consequences of greater brand equity, then to invest not just in the traditional brand-building areas of advertising, event sponsorships, or philanthropy, but also in the employees who make the brand what it is.

The first step for a marketing/HR partnership involves analysis of which categories of employees contribute the most to brand equity. They may make inventory decisions, turn non-buyers into buyers on the sales floor, train a firm's salespeople, be those salespeople, or train the customer-facing employees of channel partners. One consulting firm specifically advises that brand priorities should determine the requisite competencies of those who hire and assess employees. ${ }^{34}$

A decade ago, such advice led ING Direct (USA) to use a hiring approach to position the company as the "rebel" in the industry when they first decided to offer their banking services completely online. ING initiated a policy of recruiting 
employees from non-banking backgrounds who were encouraged to think outside the box to help their customers. ${ }^{35}$

Decisions to hire employees to embody brand values become easier to justify as technology continually changes service encounters by increasing retail self-service and by reducing person-to-person interaction to a minimum via internet marketing. This evolution focuses brand-influence opportunities on the few encounters that remain, particularly for technical service and complaint handling.

Companies should therefore try to "hire the best" and enhance their attractiveness as a place to work by viewing themselves as an "employer brand." ${ }^{36}$ Displaying values such as corporate social responsibility matters to prospective employees and aligns favorably the images of the company's brands with those of the company itself. $^{37}$ Ind defines such values as a way of working and communicating. As examples he offers being innovative, professional, team-focused, and challenging in contrast to being old-fashioned, amateurish, individualistic, and complacent. ${ }^{38}$

Sometimes, managers will implement such ideas by paying more than the industry norm to employ individuals who will delight customers, rather than merely satisfy them. They will focus on training beyond the performance of job responsibilities, to communicate how the brand that employees represent differs from its competitors. Neuhaus Belgian chocolates are a taste and texture experience, but employees of the retail stores that sell them are being trained to realize that they, as well as the chocolates, distinguish the brand. To the extent that any employee group is evaluated not only on sales and profitability data but also on customer perceptions of the brand, the traditional HR functions of hiring, training, and evaluating have benefited from a branding perspective-and so, as a consequence, has brand equity.

Internal communication is vital, and it requires telling employees convincingly and frequently that they are the brand. Noble and Mokwa, who measured the antecedents of employee commitment, emphasize the need for managers to be "champions" of what they describe as "organizational buy-in." ${ }^{39}$ Sartain uses Yahoo! as her example in noting that internal branders sell their organization's value proposition inside the organization. ${ }^{40}$

Research among employees should come first. As sensible companies do not market new products without ascertaining the readiness of the marketplace for novelty, sensible companies ascertain first what employees believe about their role in branding before starting to market suggested actions. For example, before telling workers how to spread the word on social media about specific elements of a company's service package, the obvious need is to discern whether they find that package something to boast about or to complain about-and in either case, how they perceive the brand's strengths and weaknesses.

Once employees have been consulted and suggested changes put into effect, those employees can certainly influence brand equity via social media. The Chipotle restaurant chain, with more than 1,200 stores, employs three staff members to respond to Facebook and Twitter posts. Each team member responding on behalf of the chain signs his or her name at the end of a tweet/post, and each tries if feasible to include a comment specific to the person he or she is answering. ${ }^{41}$ 
While for these employees social media is their job, other employees may go beyond their job responsibilities to blog, for example, about how someone in their company helped a customer solve a problem. A parallel action is the email message from the supermarket chain executive about the chain's new store and the accompanying publicity. Prompting such activities, exemplifying the role of brand ambassador, is "brand commitment," found by Kimpakorn and Tocquer ${ }^{42}$ to correlate positively with brand equity. Their measurement scales are similar to those employed in the "net promoter" measurement instrument discussed earlier: "I usually tell my friends that this is a great brand to work for;" and interestingly "I would accept almost any type of job assignment on order to keep working for this brand."

What might lead to such commitment? One answer is a winning-twice approach: celebrating employees in communications to customers. Shell Oil for several years ran quarter-page newspaper ads highlighting the contributions of one employee per month in each city in which shell had a facility. The ad showed the employee's picture and a description of his or her outstanding work for Shell customers.

More recently, in mid-2013, a mass-mailed four-color brochure showing merchandise from The Container Store took a similar approach. A two-page story told its readers that when the company asked employees to describe the store in one word "that represents their unique interests and backgrounds," Stacy, an 8-year employee, selected "Journey." The brochure copy went on to say that "when everyone connected to our business is happy and well cared for, it creates a far more enjoyable journey for all" - and added that 10-year employees receive an extra two weeks of vacation as a paid sabbatical; 20-year employees receive two round-trip tickets anywhere in the U.S., an extra week of vacation, and \$1000 spending money. Here was a company spreading one message derived from our study: managers who use resources to gain commitment from the employees who make the brand what it is are thereby investing in brand equity.

Another, complementary approach to gaining commitment is to promote support for employees from co-workers, according to research by Chiaburu and Harrison. ${ }^{43}$ Their meta-analysis of co-worker effects on perceptions, attitudes, organizational citizenship behaviors, and performance highlights the influence of co-worker support on the upside-and co-worker antagonism on the downside. A reasonable conclusion: how employees get along with each other is worth considering in hiring, then monitoring, then rewarding or punishing.

Heskett et al. refer to this process of encouraging employees to treat each other well and to motivate each other as "internal service quality," and call it an influence on value delivered to the customer. ${ }^{44}$ People who look forward to coming to work may do so for many reasons, but the way their co-workers treat them is one of those reasons. It influences how they perceive their company and its offerings in the marketplace. It influences effort and enthusiasm. Therefore, it influences actions that can be brand-builders-or not. And it suggests to managers that such expenses as free coffee in the break room may actually serve as investments in brand equity as employees socialize and enjoy each other's company. 
Similarly, how managers treat subordinates can be viewed as a branding issue. Burris, Detert, and Chiabu ${ }^{45}$ find that one predictor of psychological attachment to an organization is the ability to voice to supervisors comments that are intended to improve rather than merely to criticize. Given the emphasis in our research on the benefits of psychological attachment, it seems certainly worthwhile to help managers encourage what these researchers advocate: supervisors who truly want to hear proposed improvements.

In summary, an organization can view almost any employee-related policy or resource decision as a branding investment. Therefore, an obvious final issue is layoffs. As noted earlier, they can boost profits in the short term. However, a related question is their effect on brand equity in the longer term. If savings permit the kinds of actions we have suggested here, then a layoff can actually help the brand by allowing the diversion of resources to individuals or groups who differentiate the brand from generics or branded competition. Alternatively, those may be the very employees who are told their jobs no longer exist. Like many of the other policies discussed here, we simply suggest that among other perspectives, this decision include consideration of its effect on brand equity and on the elements that build it. Inevitably those include people.

\section{Notes}

1. See Gina Pingitore and Herb Williams-Dalgart, "Beyond Satisfaction: Connecting with Customers to Maximize Business Performance," Journal of Brand Strategy, 1/1 (April-June 2012): 57-68; Anthony J. Rucci, Steven P. Kirn, and Richard T. Quinn, "The Employee-Customer-Profit Chain at Sears," Harvard Business Review, 76/1 (January/February 1998): 83-97; James L. Heskett, Thomas O. Jones, Gary W. Loveman, W. Earl Sasser, Jr., and Leonard A. Schlesinger, "Putting the Service-Profit Chain to Work," Harvard Business Review, 72/2 (March/April 1994): 164-170.

2. Sarah Kessler, “Inside Starbucks's \$35 Million Mission To Make Brand Evangelists of Its FrontLine Workers," October 22, 2012, <www.fastcompany.com/3002023/inside-starbuckss-35million-mission-make-brand-evangelists-its-front-line-workers $>$.

3. Helen Lom, "Branding: How to Use Intellectual Property to Create Value for Your Business," World Intellectual Property Association, May 1, 2012, <www.wipo.int/sme/en/documents/ branding.htm>.

4. Kevin Lane Keller, Strategic Brand Management, $3^{\text {rd }}$ edition (Upper Saddle River, NJ: Pearson Education, 2008).

5. Chris Grannell, "Untangling Brand Equity, Value, Assets and Health," Brandchannel, November 3, 2009, <www.brandchannel.com/print_page.asp?ar_id=1460\&section=paper>.

6. Randle D. Raggio and Robert P. Leone, "The Theoretical Separation of Brand Equity and Brand Value: Managerial Implications for Strategic Planning," Brand Management, 14/5 (May 2007): 380-395.

7. William Neal and Don Strauss, Value Creation: The Power of Brand Equity (Mason, OH: Cengage Learning, 2008.)

8. Alan R. Andreasen and Philip Kotler, Strategic Marketing for Nonprofit Organizations, 6th edition (Upper Saddle River, NJ: Prentice Hall, 2003).

9. This point is made by Gary Davies, Rosa Chun, and Michael A. Kamins, "Reputation Gaps and the Performance of Service Organizations," Strategic Management Journal, $31 / 5$ (May 2010): 530-546. They define corporate reputation as the perceptions and feelings about an organization held by its multiple stakeholders, derived from communication and experience over time. It seems a broader concept than brand value: corporate reputation might, for example, influence public policy decisions consequential to a corporation, as well as purchase decisions that are the drivers of brand value.

10. Saumya Bhattachaarya, "On Layoffs, India Inc Still Leaves Employees in the Lurch," The Economic Times, February 9, 2012, <http://articles.economictimes.indiatimes.com/2012-02-09/ news/31041969_1_outplacement-employees-ge-india>. 
11. Kiah Collier "Pilots Say Labor Talks Hurting United," Houston Chronicle, June 13, 2012, pp. D1, D2.

12. Judy Strauss and Raymond Frost, E-Marketing, $5^{\text {th }}$ edition (Upper Saddle River, NJ: Prentice Hall, 2009), p. 4.

13. Robert F. Lusch and Stephen L. Vargo, "Marketing Value," Marketing News, 46/6, May 15 , 2012, p. 30.

14. Suzanne Hogan, Eric Almquest, and Simon E. Glynn, "Brand-Building: Finding the Touchpoints that Count," Journal of Business Strategy, 26/2 (2005): 11-18.

15. Celia V. Harquail, "Employer Branding vs. Employee Branding," accessed February 20, 2012, at $<$ http://authenticorganizations.com/harquail/2009/06/24/employer-branding-vs-employeebranding/>.

16. The model is described by Elmar Sauerwein, Franz Bailom, Kurt Matzler, and Hans H. Hinterhuber, "The Kano Model: How to Delight Your Customers," International Working Seminar on Production Economics, Innsbruck/Igls/Austria, February 19-23, 1996, pp. 313-327.

17. Mary Jo Bitner, Bernard H. Booms, and Mary Stanfield Tetreault, "The Service Encounter: Diagnosing Favorable and Unfavorable Incidents," Journal of Marketing, 54/1 (January 1990): 71-84.

18. Ceridwyn King and Debra Grace, "Building and Measuring Employee-Based Brand Equity," European Journal of Marketing, 44/7-8 (2010): 938-971. The quote is from page 943.

19. Sandra Jeanquart Miles and W. Glynn Mangold, "A Conceptualization of the Employee Branding Process," Journal of Relationship Marketing, 3/2-3 (2004): 65-87.

20. S. Douglas Pugh, "Service with a Smile: Emotional Contagion in the Service Encounter," Academy of Management Journal, 44/5 (October 2001): 1018-1027.

21. Nelson K.F. Tsang, Louisa Y.S. Lee, and Francis X.H. Li, "An Examination of the Relationship between Employee Perception and Hotel Brand Equity," Journal of Travel $\theta$ Tourism Marketing, 28/5 (2011): 481-497.

22. Graeme Martin, Paul J. Gollan, and Kerry Grigg, "Is There a Bigger and Better Future for Employer Branding? Facing up to Innovation, Corporate Reputations and Wicked Problems in SHRM," The International Journal of Human Resources, 22/17 (October 2011): 3618-3637.

23. Majken Schultz and Mary Jo Hatch, "A Cultural Perspective on Corporate Branding," in Jonathan E. Schroeder and Miriam Salzer-Morling, eds., Brand Culture (London: Routledge, 2006), pp. 15-31.

24. Rachel Maxwell and Simon Knox, "Motivating Employees to 'Live the Brand': A Comparative Case Study of Employer Brand Attractiveness within the Firm," Journal of Marketing Management, 25/9-10 (November 2009): 893-907.

25. Douglas E. Hughes and Michael Ahearne, “Energizing the Reseller's Sales Force: The Power of Brand Identification," Journal of Marketing, 74/4 (July 2010): 81-96.

26. Rucci et al. (1998), op. cit.

27. Frederick F. Reichheld, "The One Number You Need to Grow," Harvard Business Review, 81/12 (December 2003): 46-54.

28. Steve Muylle, Niraj Dawar, and Deva Rangarajan, "B2B Brand Architecture," California Management Review, 54/2 (Winter 2012): 58-71.

29. Alyssa Oursler, "The Booming Business of Boycotting Businesses," posted July 31, 2012, by InvestorPlace, <www.investorplace.com/2012/07/the-booming-business-of-boycotting-businesses/>.

30. Ruth Sheehan, "Texas Injury Caused by Cell Phone Use Yields \$22M Verdict," Detroit Legal News, May 29, 2012, <www.legalnews.com/detroit/133476>.

31. David Segal, "A Printer Freezes Up and the Maker Does Too," New York Times, August 18, 2012, p. B5.

32. Ron Lieber, "An Insurance Case that Flooded the Net," New York Times, August 19, 2012, pp. B1, B5.

33. Nelson D. Schwartz and Charles Duhigg, "Billions in Taxes Avoided by Apple, U.S. Inquiry Finds," New York Times, May 21, 2013, pp. A1, B2.

34. Branders Group AG, "Positioning the Brand Within Employee Behavior," August 6, 2012, <www.rebrand.com/stuff/contentmgr/files/c461476b827e10741 1443a6537adc716/miscdocs/ brand_based_competence_model_en_120806.pdf>.

35. Kurt Verweire and Lutgart Van den Berghe, "ING Direct: Rebel in the Banking Industry," Vlerick Business School Case Study, (2007).

36. See Helen Rosethorn, The Employer Brand (Burlington, VT: Ashgate Publishing, 2009).

37. Jean-Noel Kapferer makes this point in The New Strategic Brand Management, $4^{\text {th }}$ edition (London: Kogan Page, 2008).

38. This perspective on values comes from Nicholas Ind, Living the Brand, $3^{\text {rd }}$ edition (London: Kogan Page, 2007). However, this book has a great deal more to say on this topic, including 
other values like creativity, and more broadly, as noted in its subtitle: "How to Transform Every Member of Your Organization into a Brand Champion."

39. Charles Noble and Michael Mokwa, "Implementing Marketing Strategies: Developing and Testing a Managerial Theory," Journal of Marketing, 63/4 (October 1999): 57-73.

40. Libby Sartain, “Branding from the Inside Out at Yahoo!: HR's Role as Brand Builder," Human Resource Management, 44/1 (Spring 2005): 89-93.

41. Dan Klamm, "How Chipotle Uses Social Media to Cultivate a Better World," March 21, 2012, <http://mashable.com/2012/03/21/chipotle-social-media/>

42. Narumon Kimpakorn and Gerard Tocquer, "Service Brand Equity and Employee Brand Commitment," Journal of Services Marketing, 24/5 (2010): 378-388.

43. Dan S. Chiaburu and David A. Harrison, "Do Peers Make the Place? Conceptual Synthesis and Meta-Analysis of Coworker Effects on Perceptions, Attitudes, OCBs, and Performance," Journal of Applied Psychology, 93/5 (September 2008): 1082-1103.

44. Heskett et al., op. cit. Three of these co-authors offer a more complete discussion in James L. Heskett, W. Earl Sasser, and Leonard A. Schlesinger, The Service Profit Chain (New York, NY: The Free Press, 1997).

45. Ethan R. Burris, James R. Detert, and Dan S. Chiaburu, "Quitting Before Leaving: The Mediating Effects of Psychological Attachment and Detachment on Voice," Journal of Applied Psychology, $93 / 4$ (July 2008): 912-922. 
Copyright of California Management Review is the property of California Management Review and its content may not be copied or emailed to multiple sites or posted to a listserv without the copyright holder's express written permission. However, users may print, download, or email articles for individual use. 